\section{Ataques online: uma análise das estratégias de campanha negativa antes e durante a campanha presidencial de 2014 no Facebook}

\author{
[Online attacks: an analysis of \\ the negative campaign \\ strategies before and during \\ the 2014 Brazilian Presidential \\ Race on Facebook]
}

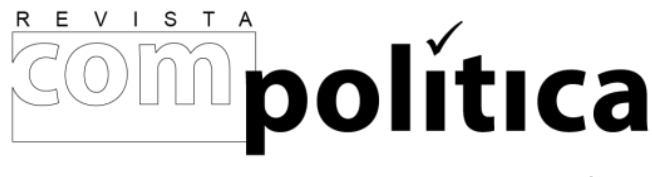

revista compolítica 2017, vol. 7(1)

compolitica.org/revista ISSN: 2236-4781

DOI: 10.21878.compolitica.2017-7.1.265 (2) Open Access Journal

\author{
Ícaro Joathan \\ Universidade Federal Fluminense \\ [Fluminense Federal University]
}

\begin{abstract}
Resumo
Este artigo visa analisar a promoção de campanha negativa no Facebook pelos dois principais candidatos à Presidência do Brasil em 2014, Dilma Rousseff e Aécio Neves, comparando as estratégias de ambos nos períodos de pré-campanha e campanha eleitoral. A pesquisa é realizada por meio da coleta das 3907 postagens publicadas nas fanpages oficiais dos dois presidenciáveis entre 6 de abril e 26 de outubro. Por meio das técnicas de Análise de Conteúdo e de Análise de Discurso, são aferidos quais posts apresentam informações com potencial de afetar negativamente a imagem dos rivais. As mensagens são classificadas quanto à frequência, ao autor, ao alvo e ao foco das críticas. Os resultados indicam o aumento das investidas no decorrer da disputa; a alternância entre Dilma e Aécio como os maiores usuários desta estratégia; a reciprocidade de um ao outro na condição de alvos majoritários; e a preferência por críticas políticas.
\end{abstract}

Palavras-chave: internet e eleições; mídias sociais; campanha negativa.

\begin{abstract}
This paper aims to analyze the negative campaign carried out on Facebook by the two main candidates running for Brazilian Presidency in 2014, Dilma Rousseff and Aécio Neves, comparing the strategies during the pre-campaign and campaign periods. The investigation is conducted by collecting the posts published in the official fanpages of the two candidates $(N=3,907)$ between 6 April and 26 October. Content analysis' and discourse analysis' techniques are taken into consideration in order to check the posts that present information with the potential to negatively affect the image of the rivals. The posts are then categorized based on frequency, author, target and focus of the attacks. The results indicate an increase in criticism during the dispute; the alternation between Dilma and Aécio as the biggest sponsors; the reciprocity of one another in the condition of main targets; and the preference of both by political attacks.
\end{abstract}

Keywords: internet and election; social media; negative campaign. 


\section{Ataques online: uma análise das estratégias de campanha negativa antes e durante a campanha presidencial de 2014 no Facebook}

eleição presidencial de 2014 no Brasil entrou para a história. O pleito
culminou no resultado mais acirrado do período pós-redemocratização: a
reeleição de Dilma Rousseff (PT), com $51,64 \%$ da preferência dos eleitores, ante 48,36\% de Aécio Neves (PSDB), pouco mais de 3,4 milhões de votos de diferença no segundo turno (Brasil, 2014).

Em relação à dinâmica da sucessão, a petista foi a primeira presidenciável após o fim da ditadura militar a vencer o primeiro turno e ser superada nas pesquisas dos institutos Datafolha e Ibope durante a segunda etapa da campanha (Freitas, 2014). Ou seja, para chegar à vitória, Dilma teve de inverter um cenário favorável ao tucano a poucos dias da votação final.

Além disso, a corrida eleitoral ficou marcada pela morte do candidato Eduardo Campos (PSB) no dia 13 de agosto, 38 dias após o início oficial da campanha. Com o falecimento do pessebista, o partido indicou sua vice, Marina Silva (PSB), que já havia sido terceira colocada no pleito de 2010, como substituta.

A entrada da ambientalista mudou o cenário da disputa. Dilma, que liderava as pesquisas com cerca de $20 \%$ de vantagem para Aécio, viu Marina aparecer em empate técnico na liderança. Esse novo cenário levou a petista e o PSDBista a mudarem a estratégia de comunicação que vinham desenvolvendo até então. Ambos recorreram à propaganda negativa entre si e contra Marina no Horário Gratuito de Propaganda Eleitoral (HGPE) de televisão (Borba, 2015; Borba; Veiga; Martins, 2015) e, como será discutido neste artigo, no Facebook.

Desde 2010, as mídias sociais passaram a integrar as estratégias de comunicação nas disputas eleitorais brasileiras. A consolidação dessas ferramentas como fenômeno comunicacional importante no âmbito da política é um dos principais fatores que justifica 
a realização da pesquisa aqui proposta. Tratam-se de novos espaços para promoção de campanha eleitoral, os quais vêm atraindo ampla atenção dos candidatos e do público. Um deles é o Facebook, rede social de maior audiência no Brasil ${ }^{1}$, a qual foi adotada por todos os presidenciáveis em 2014.

Assim, o objetivo deste trabalho é compreender e comparar as características de promoção de campanha negativa por Dilma e Aécio, em suas respectivas páginas oficiais no Facebook, durante os períodos pré-eleitoral e eleitoral de 2014, de forma a detectar eventuais variações em relação ao uso dessa estratégia entre as duas etapas. A análise busca responder a três questões principais:

a) Qual a frequência de ataque nos períodos pré-eleitoral e eleitoral no Facebook?

b) Quem ataca mais e quem é mais atacado em ambos os períodos? Há variações entre o primeiro e o segundo turnos?

c) Antes e durante o período de campanha oficial, o foco dos ataques é político, pessoal ou misto?

Os resultados indicam o aumento das investidas no decorrer da disputa; a alternância entre Dilma e Aécio como os maiores usuários da estratégia na passagem do primeiro para o segundo turno; a reciprocidade de um ao outro na condição de alvos majoritários, porém com Marina sendo a mais atacada pela petista durante quatro semanas do turno inicial; e a preferência por críticas políticas em ambos os períodos.

Inicialmente, será feita uma breve revisão teórica acerca do conceito de campanha negativa.

\footnotetext{
${ }^{1}$ Mídia social criada em 2004 que se tornou a rede social mais acessada do Brasil em dezembro de 2011. Em agosto de 2014, período da campanha presidencial, detinha cerca de $80 \%$ da audiência brasileira do segmento, com 89 milhões de usuários mensais. Ver:

http://www.meioemensagem.com.br/home/midia/noticias/2014/08/22/Facebook-tem-89-milhoes-de-usuarios-noBrasil.html (acesso em 26/09/2015).
} 


\section{A campanha negativa em disputas eleitorais}

A propaganda negativa tem registros de ser utilizada como estratégia eleitoral desde o século XVIII nas políticas norte-americana e inglesa (Borba, 2012; Dworak, 2012). Na década de 1950, com a profissionalização das campanhas nos Estados Unidos, ela começou a ser intensificada (Ansolabehere; Iyengar, 1995; Borba, 2012; Jamieson, 1992; Kaid; Johnston, 1991).

No Brasil, há registros da prática de campanha negativa desde a década de 1890 (Queiroz; Tavares, 2007), mas o fenômeno ganhou notoriedade nas primeiras eleições presidenciais após a redemocratização do País, em 1989, especialmente, pelo embate no segundo turno entre Fernando Collor de Mello (PRN) e Luiz Inácio Lula da Silva (PT) (Borba, 2012; Lourenço, 2007; Sampaio, 2013).

A origem da campanha negativa remete à ação publicitária de ressaltar atributos negativos dos concorrentes como forma de propaganda. $\mathrm{O}$ conceito pode ser definido pela ação por meio da qual "candidatos ou seus substitutos atacam ou desacreditam seus oponentes" (Ansolabehere; Iyengar, 1995, p.28)². A estratégia política tem relação direta com a publicitária, visto que os eleitores tendem a não querer correr riscos em suas escolhas políticas tanto quanto os consumidores (Ansolabehere; Iyengar, 1995).

Lourenço (2007, p.156) destaca que a propaganda negativa é "uma opção tática de campanha com finalidades e efeitos característicos". Hansen e Pedersen (2008) ressaltam que o foco dos ataques é variado, abrangendo desde a personalidade dos rivais, suas propostas, partidos, opiniões, realizações passadas, entre outras questões passíveis de críticas.

As propagandas podem ser diferenciadas por sua ênfase no patrocinador ou no alvo da mensagem. "Anúncios negativos focam em críticas ao oponente, enquanto anúncios positivos focam em características boas, realizações e emissão de posições do candidato patrocinador" (Kaid; Johnston, 1991, p.53).

\footnotetext{
${ }^{2}$ Todas as traduções apresentadas neste artigo são de responsabilidade do próprio autor.
} 
Entre os principais determinantes para a adoção da campanha negativa pelas candidaturas estão o acirramento da disputa (Lau; Pomper, 2001) e a proximidade em relação à data da votação (Damore, 2002). Na realidade brasileira, a combinação desses dois determinantes tem resultado em segundos turnos geralmente mais agressivos (Borba, 2012, 2015; Borba; Vasconcellos, 2013).

Com base nisso, a primeira hipótese deste trabalho, que visa responder à questão sobre a frequência da campanha negativa, é de que:

(H1) A frequência de ataques de Dilma e Aécio no período préeleitoral no Facebook foi mais baixa do que nos meses de campanha oficial, assim como a do primeiro turno foi menor que a do segundo.

A posição dos candidatos nas pesquisas de intenção de voto também é um indicador que induz aos ataques. Geralmente, postulantes em desvantagem atacam mais do que o líder das estimativas, o qual, por sua vez, mesmo sendo menos agressivo, prefere mirar o segundo colocado (Borba, 2012; 2015; Borba; Veiga; Martins, 2015; Damore, 2002; Elmelund-Præstekær, 2010; Walter, 2014).

A literatura mostra também que os desafiantes tendem a atacar mais do que os candidatos à reeleição (Borba, 2012, 2015; Elmelund-Præstekær, 2010; Kaid; Johnston, 1991; Klotz, 1998; Lau; Pomper, 2001; Lourenço, 2007; Walter, 2014). No Brasil, esse fenômeno é ligado ao fato de que, geralmente, as campanhas com um candidato à reeleição no Executivo são mais agressivas do que as disputas sem incumbentes (Borba, 2012, 2015; Borba; Vasconcellos, 2013).

Por todos esses indicadores, a segunda questão desta pesquisa, sobre qual candidato recorreu mais à campanha negativa, será investigada a partir da seguinte hipótese:

(H2) Aécio atacou mais do que Dilma em ambos os períodos.

A segunda questão de pesquisa visa também descobrir quais são os alvos principais dos ataques. Com base nas referências acima e considerando a contextualização a ser 
apresentada na seção deste artigo referente à conjuntura da campanha presidencial de 2014, formula-se a terceira hipótese:

(H3) Dilma foi o alvo prioritário de Aécio na pré-campanha e durante o primeiro turno. O tucano foi o alvo prioritário da petista nos dois períodos até a divulgação da primeira sondagem com a participação de Marina, a partir de quando a ambientalista passou a ser a mais atacada pela presidente ${ }^{3}$;

Em sentido oposto, o risco de o patrocinador do ataque perder intenções de votos ocasionando o chamado "efeito bumerangue" - leva os candidatos a atacarem menos, sobretudo, no primeiro turno de sistemas políticos multipartidários como o brasileiro, visto que um terceiro candidato pode ser beneficiado. A identificação pelo público da autoria do ataque e o abuso de acusações de natureza pessoal ampliam o perigo de os efeitos da estratégia se reverterem contra o autor das investidas (Borba, 2012, 2015; Elmelund-Præstekær, 2010; Hansen; Pedersen, 2008; Klotz, 1998).

Por conta desse risco, as principais pesquisas brasileiras e norte-americanas afirmam que os candidatos preferem empreender críticas focadas em atributos políticos do que pessoais. Isso porque os ataques à personalidade são vistos como menos informativos pelos eleitores (Borba, 2012; Jamieson, 1992; Kaid; Johnston, 1991; Klotz, 1998). Daí, justifica-se a hipótese que buscará responder a terceira questão desta pesquisa:

(H4) A maioria dos ataques na disputa presidencial no Facebook em 2014 foi de natureza política, tanto no período préeleitoral quanto no eleitoral.

No Brasil, outro fator que desestimula a campanha negativa é o risco de punição pelo Tribunal Superior Eleitoral (TSE), situação que pode acarretar multas, perda de tempo de

\footnotetext{
${ }^{3}$ A hipótese 3 não abrange o segundo turno porque, obviamente, Dilma e Aécio só podem ter focado suas críticas um no outro.
} 
rádio e TV no HGPE, suspensão de inserções eleitorais ao longo da programação, entre outras punições (Borba, 2012) .

\section{A propaganda negativa nas campanhas online}

No Brasil, a primeira eleição em que há registros de prática de campanha negativa online foi a disputa presidencial de 2002, quando os principais candidatos - Lula (PT), José Serra (PSDB), Anthony Garotinho (PSB) e Ciro Gomes (PDT) - utilizaram os próprios websites para transmitir informações em tempo real da disputa e atacar os adversários (Sampaio, 2013).

As campanhas políticas encontraram um novo espaço a partir de 2004, ano em que foi registrada, pela primeira vez, a influência das mídias sociais nas eleições. Esses sites passaram a ser usados para debate e expressão da opinião pública, articulação de protestos e também para os agentes políticos buscarem votos em períodos eleitorais e apoio a suas ideias em épocas não eleitorais (Aggio, 2011).

Naquele ano, a rede social Orkut tornou-se bastante popular no Brasil, contudo, nas eleições municipais, só houve registros de uso do site entre os eleitores, mas não pelos candidatos, pois a propaganda nesse espaço não era prevista pela legislação eleitoral da época (Chaia, 2007).

A restrição em relação à realização de campanha nas mídias sociais pelos candidatos só seria derrubada em 2009, a partir da sanção da Lei Federal $n^{\circ}$ 12.034. Com a regulamentação das campanhas das mídias sociais, a adesão ao Twitter pelos presidenciáveis na campanha de 2010 foi de 100\%. Quatro anos depois, o Facebook também alcançou esse índice (Carlomagno, 2015).

As pesquisas sobre o uso das mídias sociais nas eleições de 2010 e 2012 não tematizam a campanha negativa como objeto principal. A grande maioria apresenta apenas dados

\footnotetext{
${ }^{4} \mathrm{O}$ multipartidarismo e a regulamentação eleitoral excessiva no Brasil são dois fatores apontados para explicar por que historicamente as campanhas nacionais são menos negativas que as norte-americanas (Borba, 2012).
} 
percentuais acerca da incidência da estratégia entre os principais candidatos. No Twitter, por exemplo, Dilma, Serra e Marina usaram pouco esse recurso em 2010, em percentuais que variaram de 0 a 7,2\% (Aggio, 2011; Marques; Silva; Matos, 2011).

Em relação à campanha presidencial de 2014, recortes e metodologias distintos foram empregados para aferir a incidência de ataques no Facebook. Massuchin e Tavares (2015) analisaram uma amostra de cerca de $30 \%$ das postagens de Dilma, Aécio e Marina durante 90 dias do primeiro turno e codificaram 7,6\% dos posts como "ataques", 4,7\% em "ataques à administração" e 3,6\%, "defesa", além de outras categorias não mutuamente excludentes.

Penteado et al (2016) identificam os ataques promovidos por Dilma e Aécio em suas respectivas fanpages no mês de outubro de 2014 e aferem que a petista foi agressiva em $18 \%$ de suas postagens, enquanto o tucano, em 5\%. Essa categoria foi uma entre oito opções mutuamente excludentes.

Já Rossini et al (2016) verificam as postagens dos três principais candidatos durante as últimas quatro semanas do primeiro turno, por meio de duas classificações mutuamente excludentes. A primeira estabelece cinco categorias de mensagens de campanha, uma das quais a de "construção de figura pública". Dentro desta, os posts são reclassificados em seis categorias, entre as quais as de "ataque" e "contraste", nas quais são enquadradas $12 \%$ das mensagens. Os autores não incluíram no corpus mensagens compartilhadas de outras páginas, procedimento distinto do adotado neste trabalho. $\mathrm{O}$ estudo conclui pela influência das pesquisas eleitorais na decisão dos políticos em atacar os adversários.

Por fim, Joathan e Marques (2017) apresentam uma análise qualitativa acerca da campanha negativa promovida por Dilma e Aécio nos períodos de pré-campanha, campanha e pós-campanha eleitoral em 2014. O estudo apresenta os principais discursos adotados pelos candidatos para atacar os rivais no Facebook. 


\section{Contextualização: a campanha presidencial de 2014}

Desde as primeiras pesquisas de intenção de voto, ainda durante o período pré-eleitoral, percebeu-se que o pleito presidencial de 2014 teria três candidatos competitivos: a presidente Dilma Rousseff, postulante à reeleição; o senador da República Aécio Neves, eleito para o cargo em 2010 por Minas Gerais; e o ex-governador de Pernambuco, Eduardo Campos, que se desincompatibilizou do cargo em abril do ano eleitoral. Esse cenário foi comprovado no levantamento do Datafolha ${ }^{5}$ divulgado em 7 de abril de 2014, quando a petista apareceu com $38 \%$ da preferência dos entrevistados, ante $16 \%$ do tucano e $10 \%$ do pessebista.

Campos morreu em acidente aéreo em 13 de agosto, provocando comoção na corrida eleitoral. No dia 20 do mesmo mês, Marina Silva, que era vice da chapa, foi oficializada como nova titular da coligação. Com a entrada da ambientalista na disputa, o cenário mudou. Em 27 de agosto, o Ibope ${ }^{6}$ apontou Dilma com 34\%, apenas cinco pontos à frente da candidata do PSB, enquanto Aécio caiu para terceiro lugar, com $19 \%$.

Quatro dias depois, Marina confirmaria a competitividade de sua candidatura na pesquisa do Datafolha, quando apareceu empatada com Dilma, com 34\% de intenções de voto, ante $15 \%$ de Aécio.

Porém, a partir de 11 de setembro, Marina começou a oscilar negativamente e seguiu numa curva descendente, como mostra o Gráfico 1. Apesar da queda gradual da pessebista, a evolução das pesquisas reitera - ao menos, como premissa - as bases da hipótese formulada em H3, já que a pesebista só foi superada por Aécio na antevéspera do primeiro turno.

\footnotetext{
${ }^{5}$ Todas as pesquisas do Datafolha mencionadas neste trabalho estão disponíveis em http://datafolha.folha.uol.com.br/eleicoes/2014/presidente/indice-1.shtml (acesso em 03/11/2014). ${ }^{6}$ Disponível em http://www.eleicoes.ibopeinteligencia.com/Paginas/Com-o-novo-cenario-eleitoral-Dilma-e-Marina-disputariamhoje-o-segundo-turno.aspx (acesso em 03/11/2014).
} 


\section{Gráfico 1: Pesquisas de intenção de voto durante o primeiro turno}

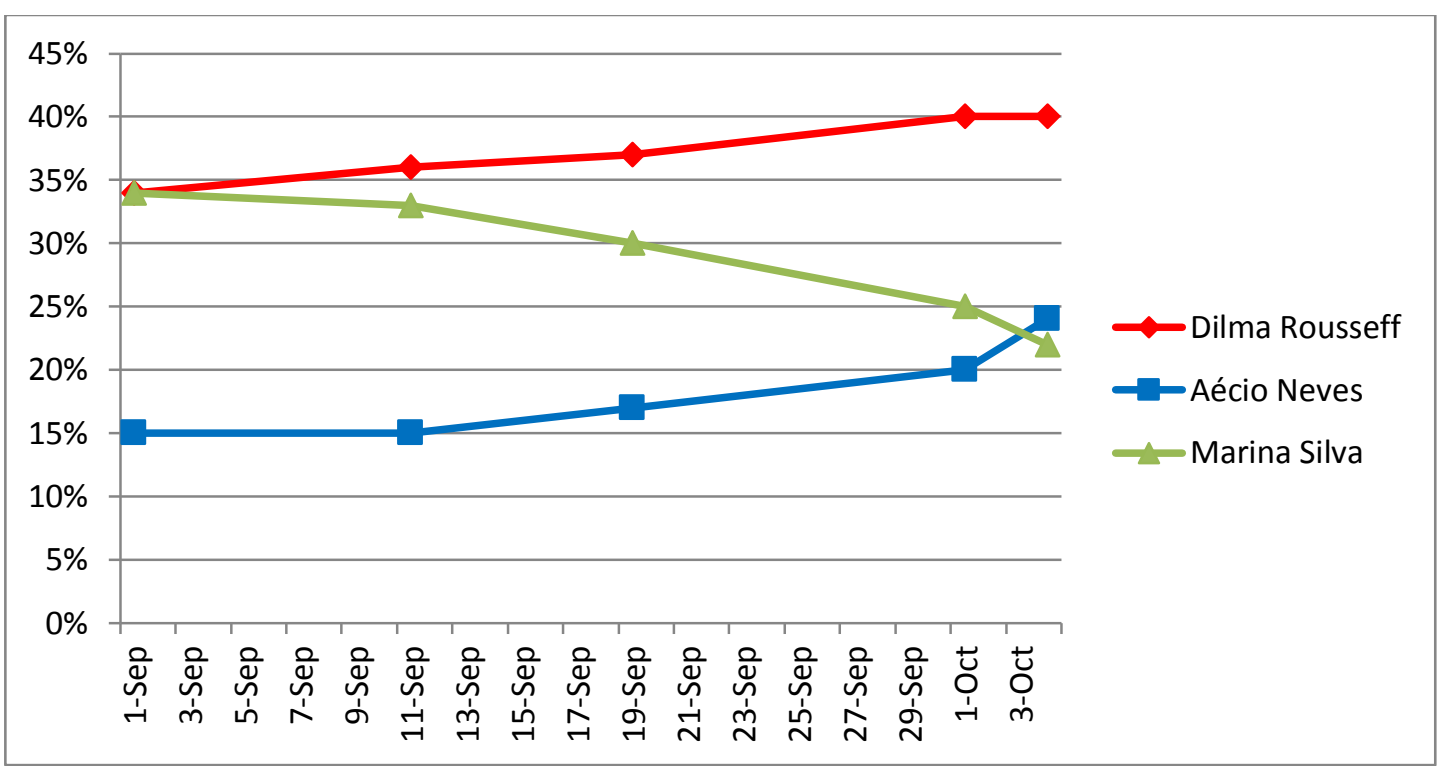

Fonte: Datafolha (2014).

O resultado final do primeiro turno indicou Dilma (41,5\% dos votos válidos) e Aécio $(33,5 \%)$ para a etapa decisiva da campanha, confirmando a queda de Marina Silva, que termina a disputa com $21,3 \%$.

O segundo turno foi, mais uma vez, polarizado entre as candidaturas do PT e do PSDB, o que vem ocorrendo no Brasil desde a eleição presidencial de 2002. Nas duas primeiras semanas, Aécio apareceu à frente nas simulações de votos, com $51 \%$, contra $49 \%$ da rival. Apenas em 21 de outubro, a cinco dias da votação final, Dilma apareceu em vantagem novamente, com $52 \%$ ante $48 \%$ de Aécio. A evolução das pesquisas do Datafolha no segundo turno está expressa no Gráfico 2: 
Gráfico 2: Pesquisas de intenção de voto durante o $2^{\circ}$ turno

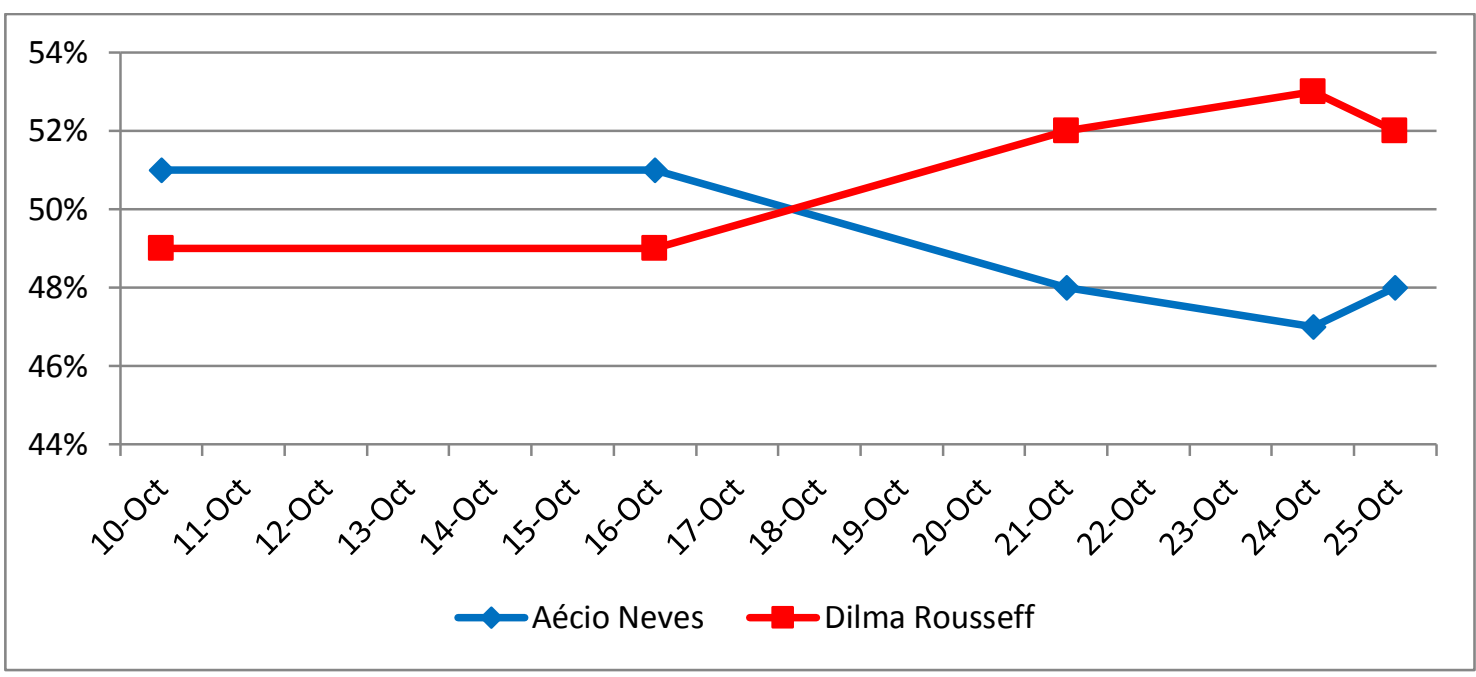

Fonte: Datafolha (2014).

O resultado final do pleito culminou na reeleição Dilma por uma margem de 3,5 milhões de votos a mais do que Aécio. A relação das 11 candidaturas da campanha presidencial brasileira em 2014, com as suas respectivas votações, é apresentada na Tabela 1.

Tabela 1: Resultado das eleições para a Presidência da República em 2014 (votos válidos)

\begin{tabular}{|c|c|c|c|}
\hline Candidato & Partido & $\begin{array}{l}\text { Votação no } \\
\text { 10 turno }\end{array}$ & $\begin{array}{l}\text { Votação no } \\
\text { 20 turno }\end{array}$ \\
\hline Dilma Rousseff & PT & $41,59 \%$ & $51,64 \%$ \\
\hline Aécio Neves & PSDB & $33,55 \%$ & $48,36 \%$ \\
\hline Marina Silva & PSB & $21,32 \%$ & \\
\hline Luciana Genro & PSOL & $1,55 \%$ & \\
\hline Pastor Everaldo & PSC & $0,75 \%$ & \\
\hline Eduardo Jorge & PV & $0,61 \%$ & \\
\hline Levy Fidelix & PRTB & $0,43 \%$ & \\
\hline Zé Maria & PSTU & $0,09 \%$ & \\
\hline Eymael & PSDC & $0,06 \%$ & \\
\hline Mauro lasi & PCB & $0,04 \%$ & \\
\hline Rui Costa Pimenta & $\mathrm{PCO}$ & $0,01 \%$ & \\
\hline
\end{tabular}

Fonte: Brasil (2014). 
Exposta a conjuntura das eleições de 2014, será apresentada agora a metodologia para a realização da investigação empírica deste trabalho.

\section{Metodologia}

O estudo aqui proposto será produzido por meio da coleta dos posts publicados por Dilma e Aécio em suas respectivas fanpages em dois períodos distintos. Para o arquivamento das mensagens, utilizou-se o aplicativo Netvizz ${ }^{7}$.

Neste estudo, considera-se como período pré-eleitoral os três meses anteriores ao início oficial de campanha estabelecido pelo TSE, portanto de 6 de abril a 5 de julho de 2014. A primeira data coincide com o prazo estabelecido pela legislação eleitoral para desincompatibilização de parte dos candidatos que tentasse concorrer à Presidência da República - caso, por exemplo, de Eduardo Campos.

O período eleitoral, de 6 de julho a 26 de outubro de 2014, é oficialmente estabelecido pelo TSE e inclui os três meses imediatamente anteriores ao primeiro turno acrescido das três semanas antes do segundo escrutínio (Brasil, 2014). A escolha de dois períodos consecutivos visa possibilitar uma comparação do uso da ferramenta pelos candidatos, a fim de verificar se há mudanças no nível de adesão à estratégia, bem como na definição dos alvos dos ataques.

Dois passos metodológicos foram estabelecidos para definir quais postagens podem ser enquadradas na categoria de campanha negativa. O primeiro deles levou em conta as diretrizes da Análise de Conteúdo e da Análise de Discurso (Bardin, 1977; Orlandi, 2000).

\footnotetext{
7 O Netvizz é um aplicativo criado para coletar dados do Facebook, incluindo fanpages. Disponível em http://apps.facebook.com/netvizz/. As postagens no período pré-eleitoral foram coletadas em $1^{\circ}$ de agosto de 2014. As coletas durante o $1^{\circ}$ turno do período eleitoral ocorreram sempre no primeiro dia do mês subsequente. As mensagens dos cinco últimos dias do turno inicial foram capturadas em 6 de outubro de 2014. Os conteúdos relativos ao $2^{\circ}$ turno foram salvos sempre no dia seguinte ao das publicações.
} 
A opção por combinar os dois métodos teve o objetivo de garantir uma categorização mais precisa dos posts. O uso da Análise de Conteúdo em pesquisas sobre campanha negativa já é consagrado (Borba, 2012; 2015; Damore, 2002; Elmelund-Præstekær, 2010; Massuchin; Tavares, 2015; Rossini et al, 2016; Walter, 2014). Porém, muitas vezes, os trechos-chave para a identificação dos ataques apareceram como metáforas, discursos implícitos ou interdiscursos, relacionados a determinados contextos sociohistóricos e ideológicos (Orlandi, 2000). Um exemplo disso é a Figura 1 (abaixo).

Figura 1: Postagem de Dilma Rousseff em 15/10/2014

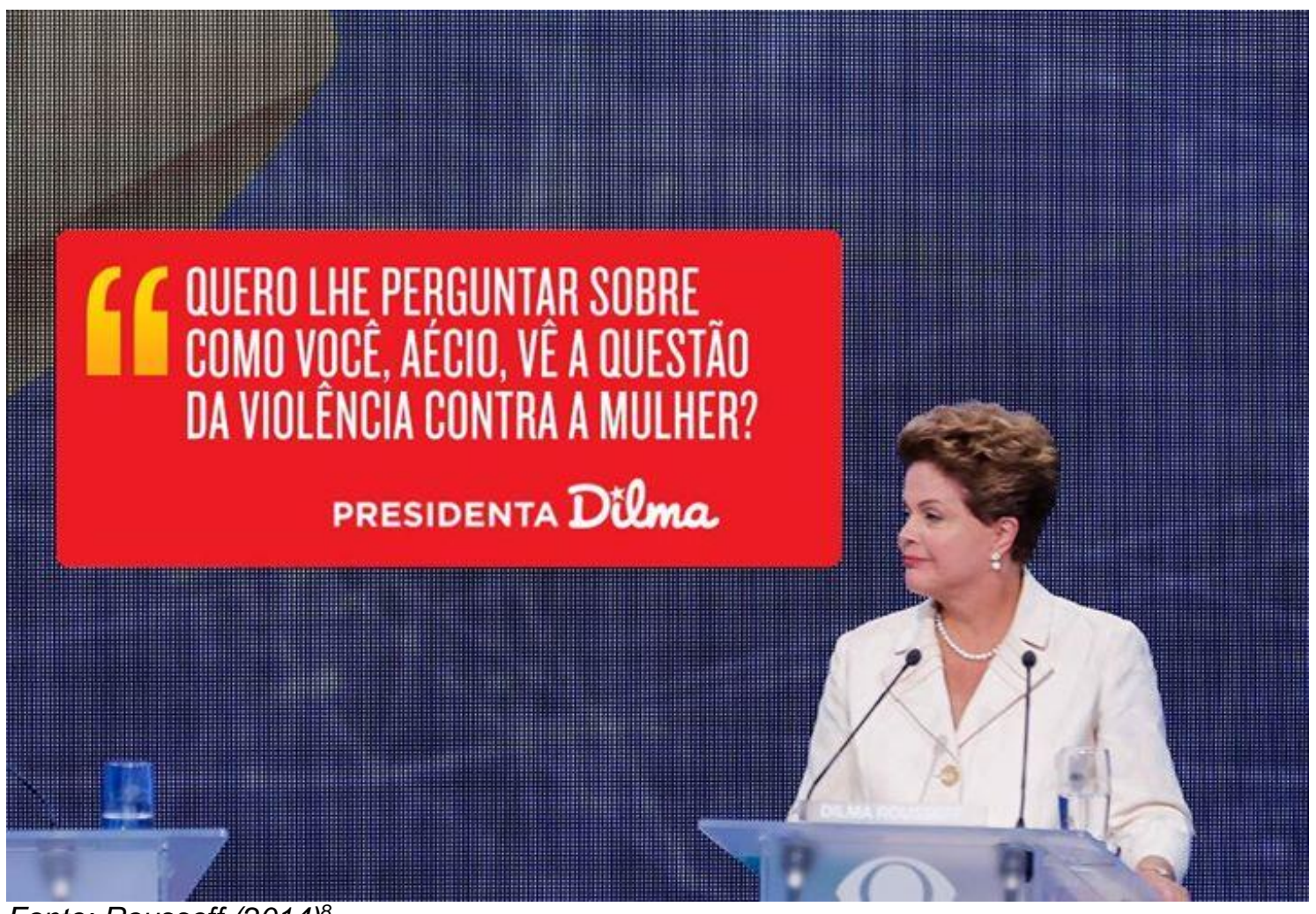

Fonte: Rousseff (2014)

Na postagem, é reproduzida uma pergunta feita pela presidente a seu rival durante um debate de televisão. Para entender que aquele questionamento era uma forma de ataque, o codificador precisa mobilizar o contexto histórico prévio de que Aécio tem contra si

\footnotetext{
${ }^{8}$ Ver http://www.facebook.com/SiteDilmaRousseff?fref=ts. Coletado pelo Netvizz em 16/10/2014.
} 
acusações de violência contra mulher ${ }^{9}$. Ou seja, a campanha negativa nesse caso está na ordem do subentendido, cuja interpretação pode ser feita com o auxílio da Análise do Discurso (Orlandi, 2000).

As postagens dos dois candidatos se constituíram como unidade de análise. Para isso, verificou-se o conteúdo e o discurso das mensagens publicadas por Dilma e Aécio em suas respectivas fanpages a partir das caracterizações de campanha negativa mais recorrentes na literatura, tais quais: (a) a apresentação de informação negativa sobre o adversário; (b) a associação de conceitos negativos ao rival, a seu partido ou a grupos políticos ligados a ele; (c) a crítica às propostas do concorrente; (d) a comparação com os oponentes, por meio da qual o autor da mensagem se define como uma opção melhor que aqueles (Dworak, 2012; Hansen; Pedersen, 2008; Jamieson, 1992; Kaid; Johnston, 1991; Sampaio, 2013).

Todos os posts publicados nas duas fanpages foram analisados, inclusive aqueles que continham vídeos, ilustrações, gráficos, áudios, links externos e conteúdos compartilhados de outros usuários. Em um primeiro momento, a codificação foi feita individualmente pelo autor do trabalho. As dúvidas (cerca de 10\% do total) foram avaliadas em conjunto com três integrantes do grupo de pesquisa Política e Novas Tecnologias (Ponte), da Universidade Federal do Ceará (UFC). Nessas ocorrências, os codificadores discutiram caso a caso até formar consenso.

O segundo passo metodológico foi submeter as postagens enquadradas como campanha negativa a uma nova classificação, com base nas categorias "frequência de ataque"; "fonte e alvo dos ataques" e "foco dos ataques", definidas a partir da adaptação dos enquadramentos de Jamieson (1992), Kaid e Johnston (1991), Klotz (1998), Lourenço (2007) e Borba (2012, 2015). A seguir, apresenta-se a definição de cada uma:

a) Frequência de ataque: busca medir, por meio do cálculo percentual da quantidade de mensagens de campanha negativa em relação ao total de postagens, a frequência de ataques de Dilma e Aécio.

\footnotetext{
${ }^{9}$ Ver "Covardia de Aécio Neves", em http://blogdojuca.uol.com.br/2009/11/covardia-de-aecio-neves/ (acesso em 30/09/2015).
} 
b) Fonte e alvo dos ataques: visa quantificar os ataques promovidos por cada emissor e quais são os seus alvos em cada crítica.

c) Foco dos ataques: divide os ataques entre os de natureza política, pessoal e mistos. A primeira classificação inclui mensagens cujo foco é a trajetória política do adversário, suas declarações, propostas e associações com outros grupos políticos. Já a segunda abrange críticas a atributos e características pessoais, como a personalidade e a vida íntima do candidato. A terceira mescla as duas anteriores. Neste trabalho, as postagens serão classificadas também quanto a uma quarta categoria, chamada "indefinida", para os casos em que não se pode determinar com clareza qual o foco principal do ataque.

\section{Apresentação dos dados}

Dilma e Aécio postaram 3907 mensagens no Facebook durante os períodos de précampanha e campanha eleitoral para a Presidência da República em 2014. Os dados por candidato e período são apresentadas na Tabela 2:

Tabela 2: Total e percentual de posts por candidato e por período

\begin{tabular}{|c|c|c|c|c|}
\hline \multirow[t]{2}{*}{ Candidato } & \multirow{2}{*}{$\begin{array}{l}\text { Período } \\
\text { pré-eleitoral } \\
\text { (6/4 a } 5 / 7 / 2014)\end{array}$} & \multicolumn{2}{|c|}{ Período eleitoral (6/7 a 26/10/2014) } & \multirow[t]{2}{*}{ Total } \\
\hline & & $\begin{array}{l}1^{\circ} \text { turno } \\
(6 / 7 \text { a } 5 / 10 / 2014)\end{array}$ & $\begin{array}{l}20 \text { turno } \\
\text { (6 a } 26 / 10 / 2014)\end{array}$ & \\
\hline Dilma & $752(71,5 \%)$ & $1103(59,3 \%)$ & $686(69 \%)$ & $2541(65 \%)$ \\
\hline Aécio & $300(28,5 \%)$ & $758(40,7 \%)$ & $308(31 \%)$ & $1366(35 \%)$ \\
\hline Total & $1052(100 \%)$ & $1861(100 \%)$ & 994 (100\%) & 3907 \\
\hline
\end{tabular}


A tabela mostra que o número de posts de Dilma foi mais do que o dobro do de Aécio na pré-campanha e no segundo turno do período eleitoral. Apenas durante o primeiro turno o senador mineiro teve um ritmo de postagens mais próximo da petista. Ambos tiveram um número alto de postagens ao longo da campanha oficial, especialmente durante o escrutínio final.

Coletadas as mensagens, o próximo passo da pesquisa é Análise de Conteúdo e a Análise de Discurso das mensagens postadas por Dilma e Aécio no Facebook. A fim de responder às perguntas desta pesquisa, os principais resultados serão apresentados em três subseções.

\section{a) Frequência de ataque}

Na soma dos períodos pré-eleitoral e eleitoral, foi identificado um total de 791 ataques dos dois políticos, o que equivale a 20,24\% do total de postagens (Tabela 3).

Tabela 3: Total e percentual de ataques por período

\begin{tabular}{l|l|l|l|l}
\hline \multicolumn{2}{l|}{ Período } & $\begin{array}{l}\text { Número de } \\
\text { posts }\end{array}$ & $\begin{array}{l}\text { Número de posts } \\
\text { de ataque }\end{array}$ & $\begin{array}{l}\text { Índice de campanha } \\
\text { negativa }\end{array}$ \\
\hline \multicolumn{2}{l|}{ Pré-eleitoral } & 1052 & 89 & $8,46 \%$ \\
\hline \multirow{2}{*}{ Eleitoral } & $\mathbf{1}^{\circ}$ turno & 1861 & 309 & $16,6 \%$ \\
\cline { 2 - 5 } & $\mathbf{2}^{\circ}$ turno & 994 & 393 & $39,54 \%$ \\
\cline { 2 - 5 } & Ambos & 2855 & 702 & $24,59 \%$ \\
\hline Total & 3907 & 791 & $20,24 \%$ \\
\hline
\end{tabular}

Fonte: $O$ autor (2017).

O número de posts e o percentual de propaganda negativa aumentam a cada etapa da disputa, chegando a impressionantes 39,5\% no segundo turno. Por durar 22 dias a mais, 
já era esperado que o período eleitoral registrasse uma quantidade de ataques superior à da pré-campanha em números absolutos. Contudo, quando a comparação é feita apenas com o turno inicial, cuja duração é praticamente a mesma (pré-campanha, 91 dias; primeiro turno, 92 dias), chama atenção o fato de a etapa oficial alcançar mais do que o triplo do número de posts negativos em relação à pré-eleitoral.

Também merece destaque o fato de o segundo turno apresentar mais ataques que o primeiro, mesmo durando apenas 21 dias. O Gráfico 3 apresenta a evolução semanal desses dados em números absolutos. Destaca-se que o período pré-eleitoral vai da semana 1 até a 13.

Gráfico 3: Total de postagens de campanha negativa por semana

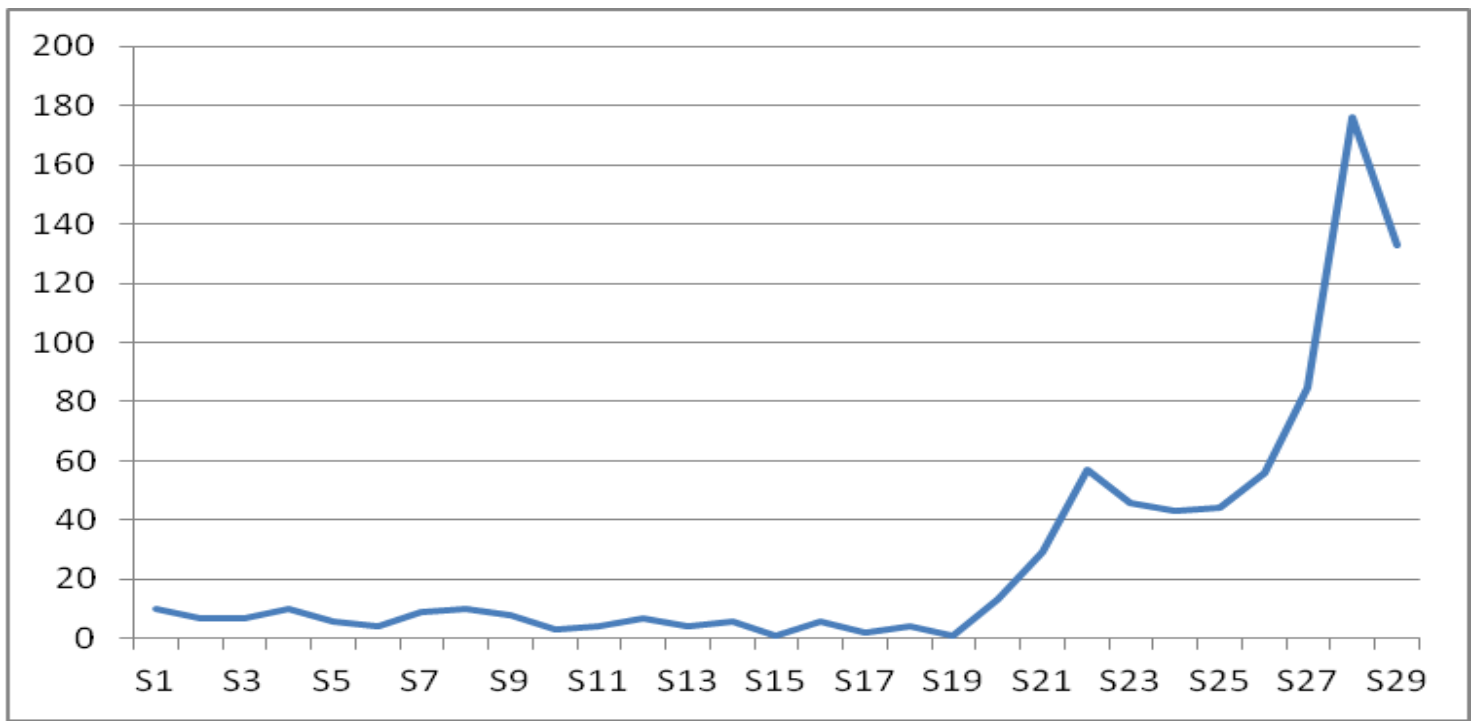

Fonte: $O$ autor (2017).

Pelo gráfico, é possível perceber que a semana 28 (a segunda do segundo turno, de 13 a 19 de outubro) foi a mais negativa da campanha e que o número de ataques era baixo até a semana 20 (17 a 23 de agosto), período que coincide com a entrada de Marina na disputa. No segundo turno (semanas 27 a 29), a ocorrência de propaganda negativa dispara. O Gráfico 4 mostra a distribuição percentual de ataques. 
Gráfico 4: Percentual de postagens de campanha negativa por semana

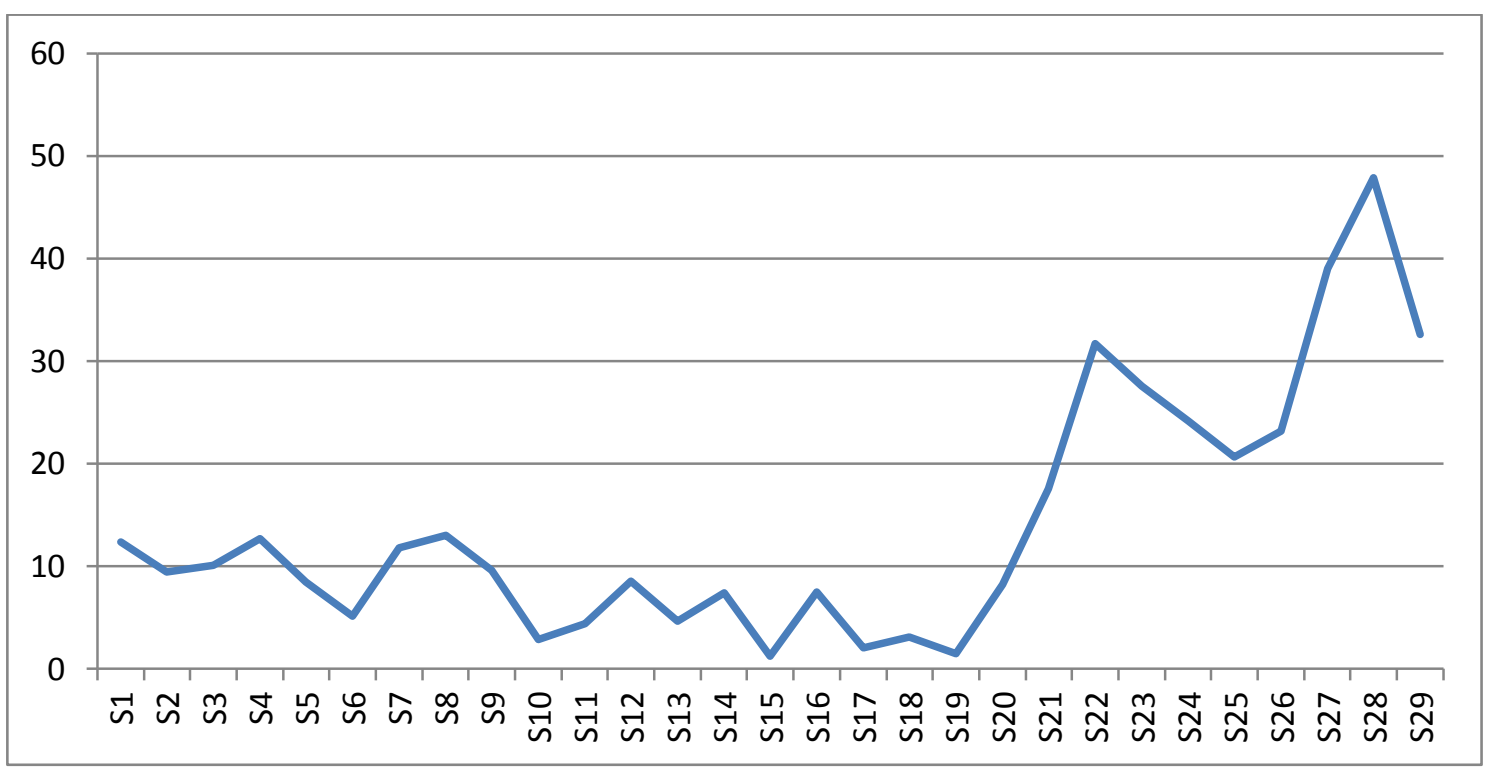

Fonte: O autor (2017).

O gráfico mostra que cinco semanas do período pré-eleitoral tiveram índice de ataques acima de $10 \%$. Depois disso, o tom permaneceu baixo e só voltou a subir na semana 21 , quando alcançou 17,6\%. A semana 22 e as três semanas do segundo turno (de 6 a 26 de outubro) registraram níveis de negatividade acima de $30 \%$.

\section{b) Fonte e alvo dos ataques}

A análise das mensagens na soma dos períodos pré-eleitoral e eleitoral indica que Dilma recorreu mais à campanha negativa em números totais, porém que Aécio adotou mais a estratégia em termos percentuais. Os dados estão apresentados na Tabela 4. 
Tabela 4: Posts classificados como campanha negativa (CN) por candidato

\begin{tabular}{|c|c|c|c|c|c|}
\hline \multicolumn{2}{|c|}{ Período } & \multicolumn{2}{|c|}{ Dilma } & \multicolumn{2}{|c|}{ Aécio } \\
\hline & & $\begin{array}{l}\text { Número de } \\
\text { ataques }\end{array}$ & Índice de CN & $\begin{array}{l}\text { Número de } \\
\text { ataques }\end{array}$ & Índice de CN \\
\hline \multicolumn{2}{|c|}{ Pré-eleitoral } & 17 & $2,26 \%$ & 72 & $24 \%$ \\
\hline \multirow[t]{3}{*}{ Eleitoral } & 10 turno & 145 & $13,15 \%$ & 164 & $21,64 \%$ \\
\hline & 20 turno & 294 & $42,86 \%$ & 99 & $32,14 \%$ \\
\hline & Ambos & 439 & $24,54 \%$ & 263 & $24,67 \%$ \\
\hline Total & & 456 & $17,95 \%$ & 335 & $24,52 \%$ \\
\hline
\end{tabular}

Fonte: $O$ autor (2017).

Se for levado em conta apenas o período pré-eleitoral e o primeiro turno, Aécio é muito mais negativo do que Dilma, inclusive em números absolutos. Apenas no segundo turno é que a presidente adota uma estratégia mais agressiva que o senador.

O Gráfico 5 mostra a variação de ataques em números absolutos. 
Gráfico 5: Evolução semanal do número de ataques dos candidatos

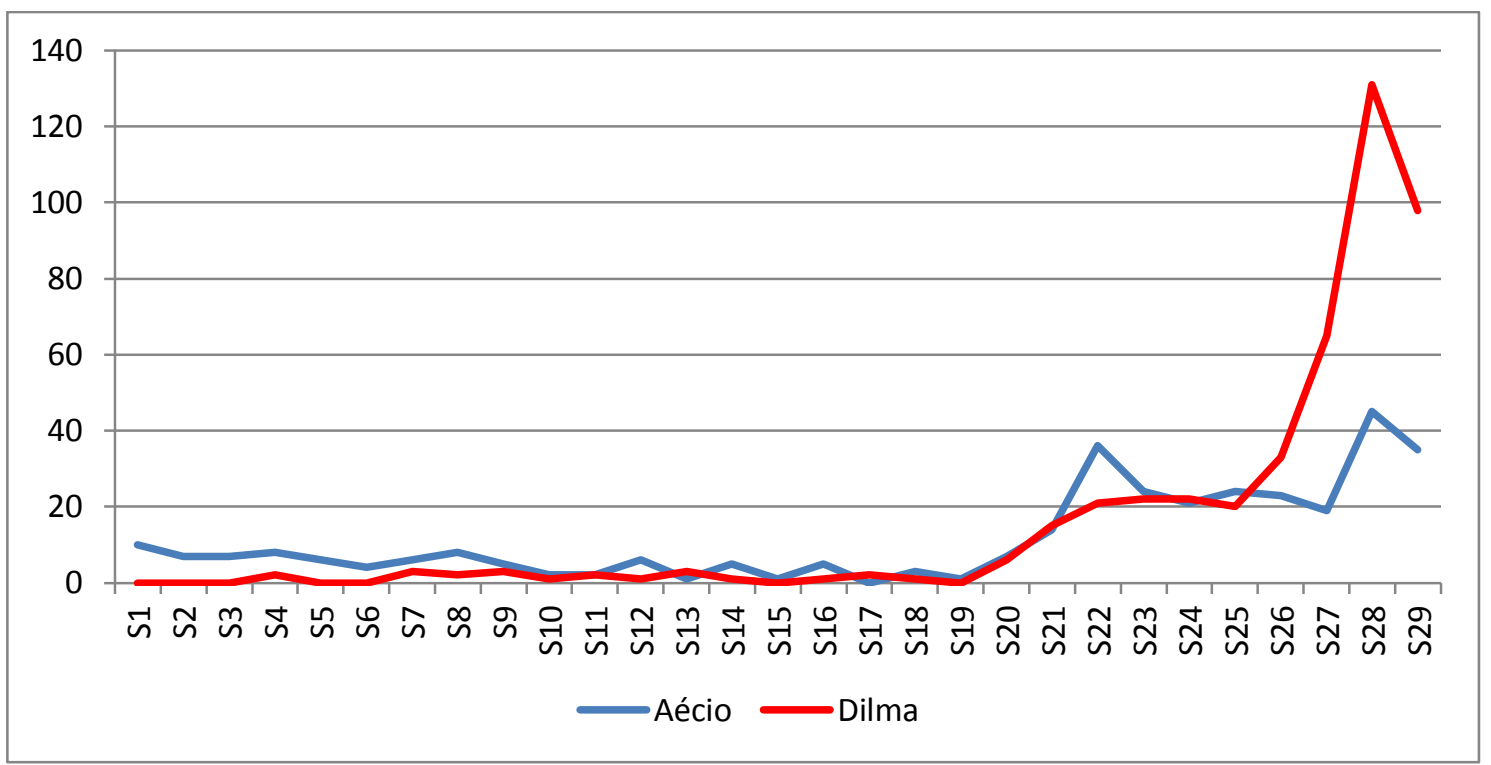

Fonte: O autor (2017).

O gráfico permite perceber que, em números absolutos, Aécio desferiu mais ataques do que Dilma durante quase todas as semanas do período pré-eleitoral - a exceção foi a semana 13 (29 de junho a 5 de julho), a última antes da campanha oficial.

Após o início do período eleitoral, o candidato do PSDB segue atacando mais até a entrada de Marina na disputa - com exceção da semana 17 ( 27 de julho a 2 de agosto). A partir da semana 21, já com a ambientalista candidata, passa a haver uma variação entre Dilma e Aécio em relação a quem é mais negativo. Na semana 26 (28 de setembro a 4 de outubro), a petista intensifica os ataques e mantém-se como a mais agressiva até o fim do segundo escrutínio.

A seguir, o Gráfico 6 apresenta a variação de ataques em termos relativos. 
Gráfico 6: Evolução semanal do percentual de ataques dos candidatos

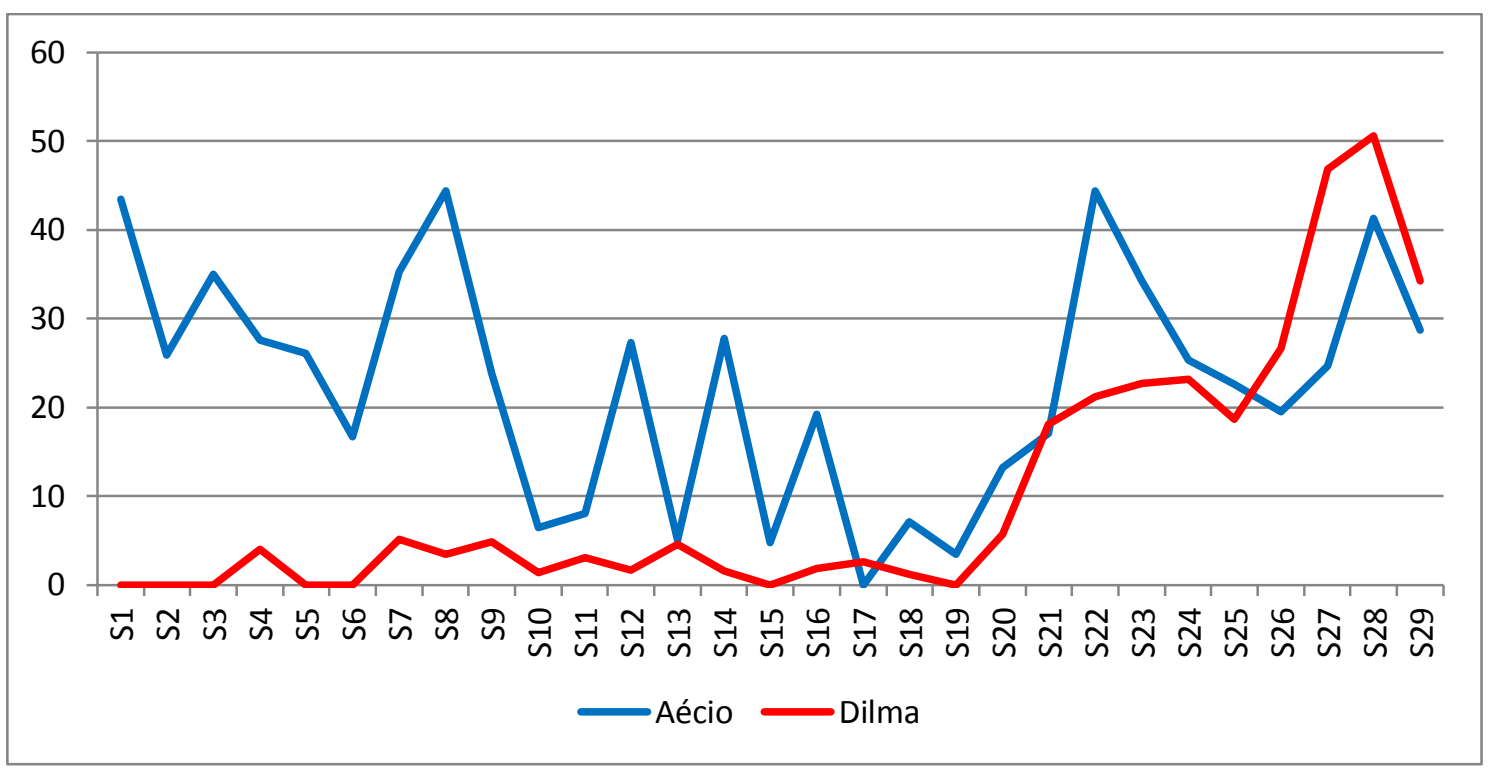

Fonte: O autor (2017).

Em termos percentuais, Aécio foi o mais negativo em toda a pré-campanha e em quase todo o período eleitoral, exceto nas semanas 17, 21, e entre as semanas 26 e 29 (28 de setembro a 26 de outubro). Esses indicadores mostram que, apesar de ter tido menos presença no Facebook, quando o fez, o senador mineiro foi mais negativo.

Além de tentar verificar quem atacou mais, esta pesquisa busca aferir quais foram os principais alvos de Dilma e Aécio. Os candidatos atacados pela petista são apresentados na Tabela 5. É preciso ressaltar que o "N" dessa categoria é superior a 100\% porque em um único post é possível atacar mais de um rival. 
Tabela 5: Alvos dos ataques de Dilma

\begin{tabular}{|c|c|c|c|c|c|}
\hline \multirow[t]{2}{*}{ Alvo } & \multirow[t]{2}{*}{ Pré-eleitoral } & \multicolumn{3}{|c|}{ Eleitoral } & \multirow[t]{2}{*}{ Total } \\
\hline & & 10 turno & 20 turno & Ambos & \\
\hline Aécio & $17(100 \%)$ & $76(52,4 \%)$ & $294(100 \%)$ & $370(84,3 \%)$ & $387(84,9 \%)$ \\
\hline Marina & 0 & $66(45,5 \%)$ & $4(1,4 \%)$ & $70(15,9 \%)$ & $70(15,4 \%)$ \\
\hline Indefinido & 0 & $25(17,2 \%)$ & 0 & $25(5,7 \%)$ & $25(5,5 \%)$ \\
\hline Campos & $2(11,8 \%)$ & $1(0,7 \%)$ & 0 & $1(0,2 \%)$ & $3(0,7 \%)$ \\
\hline Levy & 0 & $1(0,7 \%)$ & 0 & $1(0,2 \%)$ & $1(0,2 \%)$ \\
\hline Todos & 0 & $1(0,7 \%)$ & 0 & $1(0,2 \%)$ & $1(0,2 \%)$ \\
\hline $\begin{array}{l}\text { Total de } \\
\text { ataques }\end{array}$ & $17(100 \%)$ & $145(100 \%)$ & $294(100 \%)$ & $439(100 \%)$ & 456 (100\%) \\
\hline
\end{tabular}

Fonte: $O$ autor (2017).

Aécio foi o alvo prioritário de Dilma durante todos os intervalos analisados, porém é preciso destacar que, no primeiro turno, Marina recebeu quase a mesma quantidade de ataques que o PSDBista. Entre os dias 28 de agosto e 24 de setembro - período que compreende desde o fim da semana 21 até o início da semana 25 -, a substituta de Campos foi a mais alvejada pela presidente, como atesta o Gráfico 7. 
Gráfico 7: Alvos dos ataques de Dilma por semana (números absolutos)

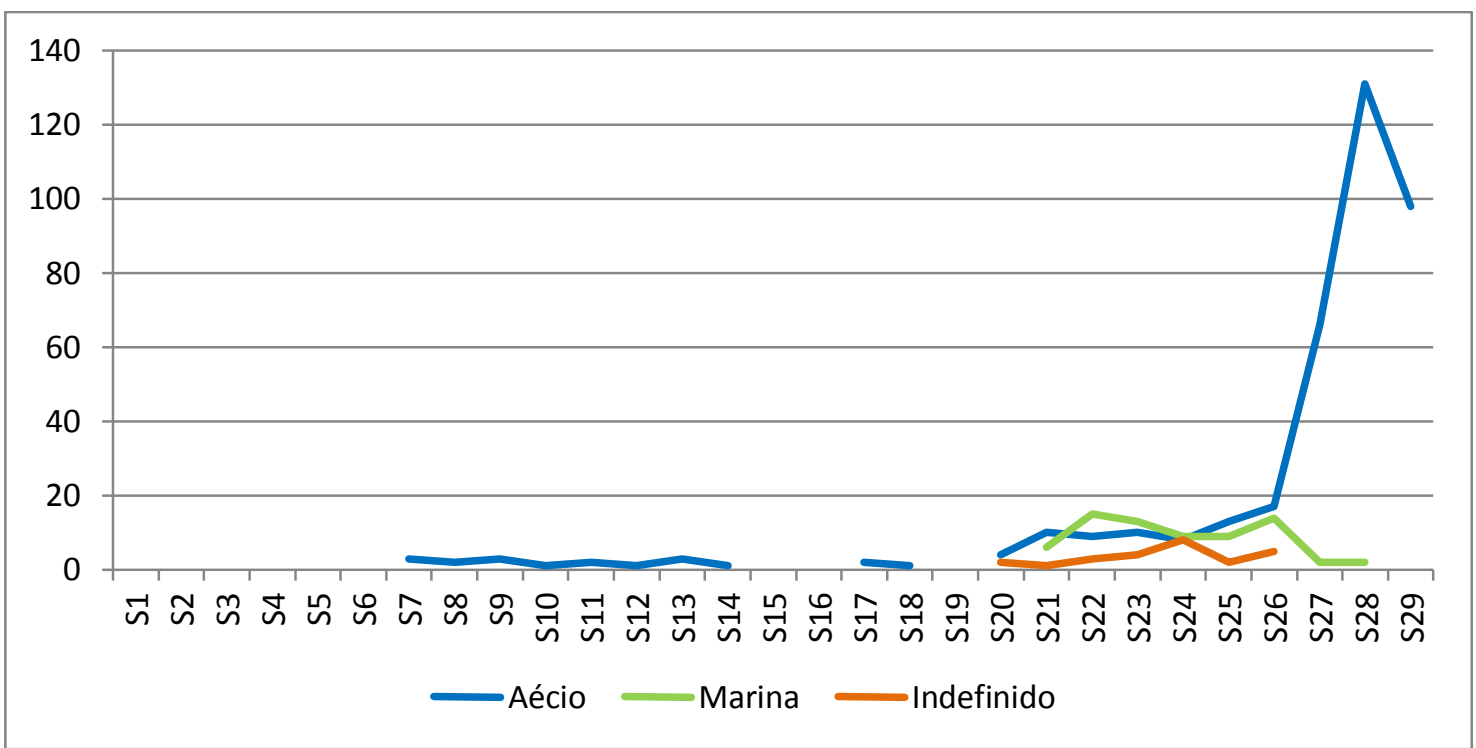

Fonte: O autor (2017).

Vale reiterar que Marina só entrou na disputa no meio da semana 20, ou seja, enquanto esteve na disputa, ela dividiu com Aécio a condição de alvo-mor de Dilma. Com o detalhe de que a ambientalista só foi candidata durante 47 dias, enquanto o senador esteve em todos os 92 dias do escrutínio inicial.

Por sua vez, os alvos prioritários de Aécio são apresentados na Tabela 6. 
Tabela 6: Alvos dos ataques de Aécio

\begin{tabular}{|c|c|c|c|c|c|}
\hline \multirow[t]{2}{*}{ Alvo } & \multirow[t]{2}{*}{ Pré-eleitoral } & \multicolumn{3}{|c|}{ Eleitoral } & \multirow[t]{2}{*}{ Total } \\
\hline & & 10 turno & 20 turno & Ambos & \\
\hline Dilma & $72(100 \%)$ & $153(93,3 \%)$ & $99(100 \%)$ & $252(95,8 \%)$ & $324(96,7 \%)$ \\
\hline Marina & 0 & $64(39 \%)$ & 0 & $64(24,3 \%)$ & $64(19,1 \%)$ \\
\hline Indefinido & 0 & $2(1,2 \%)$ & 0 & $2(0,8 \%)$ & $2(0,6 \%)$ \\
\hline Luciana & 0 & $1(0,6 \%)$ & 0 & $1(0,4 \%)$ & $1(0,3 \%)$ \\
\hline $\begin{array}{l}\text { Total de } \\
\text { ataques }\end{array}$ & $72(100 \%)$ & $164(100 \%)$ & $99(100 \%)$ & $263(100 \%)$ & $335(100 \%)$ \\
\hline
\end{tabular}

Os dados comprovam que Dilma recebeu bem mais ataques de Aécio, tanto no período pré-eleitoral, quando apenas ela foi atacada, quanto em toda a campanha oficial, já com Marina na disputa.

Apesar de a petista ter sido o alvo prioritário do tucano em todos os momentos analisados, entre as semanas 22 e 25 (de 31 de agosto a 27 de setembro), Marina recebeu número considerável de ataques do senador mineiro, como mostra o Gráfico 8. 
Gráfico 8: Alvos dos ataques de Aécio por semana (números absolutos)

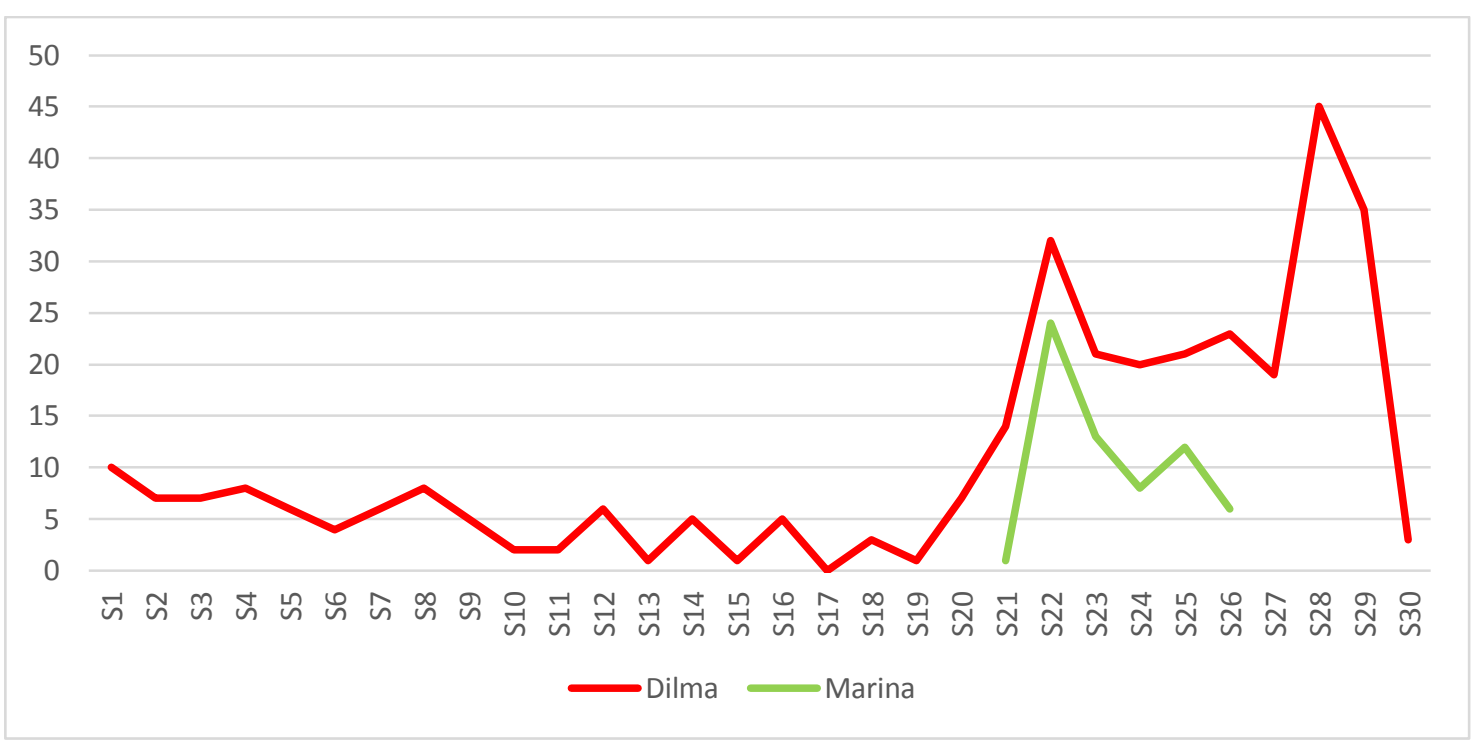

Fonte: O autor (2017).

\section{c) Foco dos ataques}

Como já explicado, o foco dos ataques promovidos em estratégias de campanha negativa neste trabalho será classificado em político, pessoal, misto ou indefinido. Tratam-se de classificações mutuamente excludentes, ou seja, o "N" dessa categoria é igual a 100\% das mensagens negativas de cada candidato.

A divisão de ataques por foco e período está expressa na Tabela 7. 
Tabela 7: Foco dos ataques por período e por candidato em números absolutos

\begin{tabular}{|c|c|c|c|c|c|c|}
\hline Período & Candidato & Político & Pessoal & Misto & Indefinido & Total \\
\hline \multirow[t]{2}{*}{ Pré-eleitoral } & Dilma & $\begin{array}{c}15 \\
(88,2 \%)\end{array}$ & $2(11,8 \%)$ & 0 & 0 & $\begin{array}{c}17 \\
(100 \%)\end{array}$ \\
\hline & Aécio & $\begin{array}{c}71 \\
(98,6 \%)\end{array}$ & 0 & $1(1,4 \%)$ & 0 & $\begin{array}{c}72 \\
(100 \%)\end{array}$ \\
\hline \multirow[t]{2}{*}{ Eleitoral } & Dilma & $\begin{array}{c}296 \\
(67,4 \%)\end{array}$ & $\begin{array}{c}60 \\
(13,7 \%)\end{array}$ & $\begin{array}{c}75 \\
(17,1 \%)\end{array}$ & $8(1,8 \%)$ & $\begin{array}{c}439 \\
(100 \%)\end{array}$ \\
\hline & Aécio & $\begin{array}{c}179 \\
(68,1 \%)\end{array}$ & $20(7,6 \%)$ & $\begin{array}{c}64 \\
(24,3 \%)\end{array}$ & 0 & $\begin{array}{c}263 \\
(100 \%)\end{array}$ \\
\hline \multicolumn{2}{|c|}{ Total } & $\begin{array}{c}561 \\
(70,9 \%)\end{array}$ & $\begin{array}{c}82 \\
(10,4 \%)\end{array}$ & $\begin{array}{c}140 \\
(17,7 \%)\end{array}$ & $8(1 \%)$ & $\begin{array}{c}791 \\
(100 \%)\end{array}$ \\
\hline
\end{tabular}

Fonte: $O$ autor (2017).

Os dados demonstram que Aécio atacou com foco político quase cinco vezes mais que Dilma no período pré-eleitoral $(71 \times 15)$. Na fase oficial da campanha, porém, a presidente supera o senador em todas as categorias, inclusive na de ataques pessoais (60x20), foco o qual a petista usa mais que o concorrente em ambos os períodos.

$\mathrm{Na}$ soma dos dois períodos, ambos os candidatos preferem lançar mão de ataques políticos (561), seguidos das críticas de natureza mista (140) e, por último, as mensagens negativas pessoais (82).

Percentualmente, porém, Aécio empreendeu mais ataques políticos e mistos que Dilma não apenas no período pré-eleitoral, mas também durante a campanha oficial. A presidente, por sua vez, usou mais a estratégia de críticas pessoais em ambas as etapas. 


\section{Discussão dos resultados}

Os dados expostos na seção anterior ajudam a caracterizar como se deu a promoção de campanha negativa no Facebook durante as eleições presidenciais de 2014 por Dilma Rousseff e Aécio Neves, e permitem agora discutir esses achados e as hipóteses de investigação formuladas.

Em relação à frequência de ataque, a análise indicou que os dois presidenciáveis postaram 791 mensagens negativas entre 6 de abril e 26 de outubro de 2014, o equivalente a 20,24\% do total de publicações feitas por ambos. Esse índice pode ser considerado alto, tomando como base estudos anteriores sobre o uso desse tipo de estratégia em mídias sociais por candidatos nas eleições de 2010 e 2012, o qual não superou os 7,2\% (Aggio, 2011; Marques; Silva; Matos, 2011).

Um dos fatores que explica esse índice é o fato de as eleições presidenciais de 2014 terem sido as mais concorridas desde a redemocratização do País, pois o acirramento é um indicador que, geralmente, eleva o tom das disputas. Outro elemento a ser considerado é que o pleito envolveu uma candidata à reeleição, cenário que costuma tornar as disputas mais agressivas (Borba, 2012, 2015; Borba; Vasconcellos, 2013; Borba; Veiga; Martins, 2015).

No que tange à hipótese 1 (H1), por meio da qual previu-se que "a frequência de ataques no período pré-eleitoral no Facebook foi mais baixa do que nos meses de campanha oficial, assim como a do primeiro turno foi menor que a do segundo", é possível confirmá-la. Ao todo, o período eleitoral teve $24,59 \%$ de campanha negativa no Facebook, sendo $16,6 \%$ no primeiro turno e 39,5\% no segundo. Já na pré-campanha, esse índice ficou em $8,5 \%$.

Esse comportamento tem relação com a diminuição no uso das mídias sociais pelos políticos em períodos não eleitorais, como demonstra o caso da própria Dilma que, após se eleger em 2010, passou quase três anos sem utilizar o microblog (Marques, Silva; 
Matos, 2011). O risco de punição pelo TSE por propaganda eleitoral antecipada é outro elemento que deve ser considerado para explicar porque os candidatos atacam menos antes do período oficial. $\mathrm{O}$ aumento da frequência de posts de campanha negativa à medida que a eleição se aproxima pode ser explicado também pela tentativa dos concorrentes de ganhar votos dos eleitores indecisos (Borba, 2012; Borba; Vasconcellos, 2013; Damore, 2002).

Ainda em relação a esse achado cabe comentar certa disparidade em relação a outras pesquisas já divulgadas sobre a eleição presidencial de 2014 no Facebook. Os estudos de Massuchin e Tavares (2015), Rossini et al (2016) e Penteado et al (2016) tiveram recortes distintos em relação a tempo e escolha dos candidatos a serem analisados, além da metodologia empregada, como já assinalado na seção 3 deste paper.

A comparação entre os trabalhos torna-se, assim, inviável, porém defendemos três escolhas metodológicas tomadas nesta pesquisa. A primeira delas é a análise das postagens para aferição da presença ou não de campanha negativa como uma categoria não mutuamente excludente, ou seja, uma variável dummy, independente de outras categorias de postagens, como mobilização, agenda, engajamento, informação etc. Várias pesquisas nacionais e internacionais têm adotado esta perspectiva (Damore, 2002; Elmelund-Præstekær, 2010; Massuchin; Tavares, 2015; Joathan; Marques, 2017; Walter, 2014). A segunda é a utilização combinada das metodologias de Análise de Conteúdo e de Discurso, de forma a perceber os ataques inclusive quando eles se dão por discursos implícitos ou associados a contextos específicos (Joathan; Marques, 2017). A terceira é a verificação de todas as mensagens publicadas nas fanpages dos políticos, inclusive daquelas cujo conteúdo negativo está presente em vídeos, sites externos cujo link é inserido no post, áudios e postagens compartilhadas de outras páginas e/ou usuários. A exclusão desses conteúdos resultaria em um índice de negatividade inferior ao realmente praticado pelos candidatos e, por isso, se justifica a necessidade de incluí-los no corpus (Joathan; Marques, 2017).

Quanto à segunda questão de pesquisa, sobre as fontes e alvos de ataque, os resultados confirmam parcialmente $\mathrm{H} 2$, a qual estimou que "Aécio atacou mais do que Dilma em ambos os períodos". Essa assertiva verificou-se em termos percentuais nos dois períodos, 
mas não em números absolutos, no que se refere à campanha oficial, especialmente ao segundo turno.

Durante o período pré-eleitoral, Aécio atacou Dilma em 72 posts, correspondentes a $24 \%$ das mensagens postadas em sua fanpage, ao passo que a petista desferiu apenas 17 ataques $(2,26 \%)$.

Considerando apenas o período eleitoral, a situação se mantém em termos relativos, visto que Aécio atacou em $24,7 \%$ de seus posts, ao passo que Dilma criticou rivais em 24,5\%. Em números absolutos, porém, a petista é quem mais recorre à propaganda negativa, publicando 439 ataques, ao passo que o tucano o faz 263 vezes no Facebook. Pesou para isso o segundo turno, ocasião em que Dilma atacou em $42,9 \%$ de seus posts contra $32,1 \%$ do senador, o que equivale a 294 investidas da presidente ante 99 do rival.

O fato de Dilma ter atacado mais do que Aécio em números absolutos no período eleitoral e também em termos relativos no segundo turno surpreende, pois é mais comum que os desafiantes ataquem mais (Borba, 2012; Kaid; Johnston, 1991; Klotz, 1998; Lourenço, 2007).

A explicação mais plausível para essa mudança de comportamento por parte da petista está no fato de ela ter sido ultrapassada por Aécio nas primeiras sondagens do segundo turno, ou seja, sua reeleição estava sob ameaça. A reduzida força política de Dilma na época, que enfrentava baixa popularidade desde as manifestações de junho de 2013 e os escândalos de corrupção envolvendo membros de seu governo, também é apontada por Borba, Veiga e Martins (2015) como uma razão para a presidente ter se tornado bem mais agressiva que o seu concorrente nas inserções televisivas do $2^{\circ}$ turno.

Em relação à H3, a assertiva também foi parcialmente confirmada. Dilma, de fato, foi o alvo único de Aécio na pré-campanha e o prioritário durante todo o primeiro turno. $\mathrm{O}$ tucano sofreu a maioria dos ataques da petista até a divulgação da primeira sondagem com a participação de Marina, a partir de quando a ambientalista passou a ser a mais atacada pela presidente. 
Todos esses cenários estão alinhados aos determinantes da campanha negativa citados neste trabalho, os quais asseveram que a posição dos candidatos nas pesquisas é determinante para a escolha do alvo a ser atacado.

A parte não confirmada da hipótese se dá entre 25 de setembro e 5 de outubro, os 11 últimos dias do primeiro turno, período em que Dilma volta a mirar Aécio como alvo principal, mesmo com Marina mantendo-se em segundo lugar nas pesquisas até 3 de outubro. Provavelmente, essa mudança de estratégia por parte da petista no Facebook levou em conta a tendência de crescimento que o tucano vinha apresentando desde meados de setembro, bem como a queda progressiva das intenções de voto da ambientalista a partir da mesma data.

Essa situação mostra que não apenas a posição dos candidatos nas pesquisas é levada em conta para definir uma estratégia de propaganda negativa, mas as respectivas tendências de crescimento e queda nos diferentes momentos da campanha.

Ainda em relação aos alvos prioritários de cada presidenciável, percebe-se que Aécio, apesar de ter atacado Marina em 64 postagens no primeiro turno, tentou preservar uma possível aliança com a ambientalista na segunda etapa da corrida eleitoral, interesse comum em sistemas políticos multipartidários como o brasileiro (Borba, 2012, 2015; Elmelund-Præstekær, 2010; Hansen; Pedersen, 2008). O apoio da pessebista ao tucano, de fato, se confirmou.

Por fim, a terceira pergunta desta pesquisa buscou aferir o foco principal das críticas. Os resultados confirmaram a $\mathrm{H} 4$, pois "a maioria dos ataques na disputa presidencial no Facebook em 2014 foi de natureza política, tanto no período pré-eleitoral quanto no eleitoral".

As críticas com foco político responderam por 70,9\% do total de mensagens de campanha negativa. Considerando apenas o período pré-eleitoral, quase todos os ataques foram de natureza política $(96,6 \%)$. O índice de críticas de natureza política no período eleitoral foi de $67 \%$, acima da média de $60 \%$ de ataques com foco político no HGPE televisivo entre 1989 e 2014 (Borba, 2015). 
Em termos relativos, Aécio utilizou mais os ataques políticos do que Dilma $(74,5 \% \mathrm{x}$ $68,2 \%)$, enquanto a petista recorreu mais às críticas pessoais do que seu rival $(13,6 \% \mathrm{x}$ $5,9 \%$ ). Sobre esses resultados, é interessante ponderar que já era esperado que Aécio recebesse mais ataques pessoais, em virtude de ter mais fatos relacionados à vida privada expostos na mídia do que a presidente, cuja intimidade é pouco conhecida ${ }^{10}$.

\section{Considerações finais}

A pesquisa aqui apresentada teve o objetivo de compreender as estratégias de promoção da propaganda negativa no Facebook pelos dois principais candidatos à Presidência do Brasil - Dilma Rousseff (PT) e Aécio Neves (PSDB) - durante a pré-campanha e o período eleitoral de 2014.

Para operacionalizar a pesquisa, foram coletadas todas as 3907 publicações das fanpages oficiais dos dois postulantes ao Palácio do Planalto entre 6 de abril e 26 de outubro de 2014, das quais 791 foram identificadas como propaganda negativa.

As mensagens foram classificadas quanto à frequência; ao autor e ao alvo; e ao foco dos ataques. Os resultados indicaram que os candidatos utilizaram bem mais a campanha negativa no período eleitoral do que no pré-eleitoral, assim como no segundo turno o índice de negatividade mais do que duplicou em relação ao primeiro. O estudo demonstrou que o tucano usou mais a estratégia do que a petista antes do período oficial de campanha e no primeiro turno, mas que, na etapa final, a presidente atacou mais tanto em números absolutos quanto em termos percentuais.

Além disso, a pesquisa mostrou que Dilma e Aécio tiveram um ao outro como alvo principal no Facebook até a entrada de Marina na disputa, a partir de quando a candidata do PSB passou quatro semanas como a mais alvejada pela postulante à reeleição. Por fim,

\footnotetext{
${ }^{10} \mathrm{Ver}$

http://www.jb.com.br/eleicoes-2014/noticias/2014/10/16/em-debate-no-sbt-aecio-e-dilma-trocam-acusacoessobre-corrupcao-e-nepotismo/ (acesso em 02/10/2015).
} 
o estudo demonstrou que ambos os presidenciáveis preferiram atacar com conteúdos de natureza política.

Em trabalhos futuros, acreditamos que novas abordagens possam ser realizadas a fim de analisar outros aspectos relacionados à campanha negativa, tais como o uso de recursos multimídia nos ataques, e o papel de outras fanpages que não as oficiais dos candidatos para promover propaganda negativa na web, entre elas as de partidos, líderes políticos e movimentos sociais.

\section{Notas}

${ }^{1} \mathrm{O}$ autor agradece ao professor Francisco Paulo Jamil Marques, da Universidade Federal do Paraná (UFPR), e às pesquisadoras Simone Faustino da Silva, Aline Mendonça Conde Carneiro e Hébely da Silva Rebouças pela colaboração no desenvolvimento desta pesquisa.

\section{Referências}

AGGIO, Camilo. As campanhas políticas no Twitter: uma análise do padrão de comunicação política dos três principais candidatos à presidência do Brasil em 2010. In: 4 COMPOLíTICA. Rio de Janeiro, 13 a 15 abr. 2011. Anais... Rio de Janeiro: GT Internet e Política, 2011, p. 1-24.

ANSOLABEHERE, S.; IYENGAR, S. Going negative: How attack ads shrink and polarize the electorate. New York: The Free Press, Kobo Edition, 1995.

BARDIN, Laurence. Análise de conteúdo. Lisboa: Edições 70, 1977.

BORBA, Felipe de Moraes. A propaganda negativa: estratégia e voto nas eleições brasileiras. Tese (Doutorado em Ciência Política) - Universidade do Estado do Rio de Janeiro, Instituto de Estudos Sociais e Políticos, 2012.

Propaganda negativa nas eleições presidenciais brasileiras. Opinião Pública, v. 21, n. 2, p. 268-295, 2015.

BORBA, F. M.; VASCONCELLOS, F. Modelos de campanha, propaganda negativa e voto nas eleições municipais do Rio de Janeiro e São Paulo. In: CONGRESSO DA COMPOLÍTICA, 5., 8 a 10 mai. 2013, Curitiba. Anais... Curitiba: Compolítica, 2013.

BORBA, F. M.; VEIGA, L. F.; MARTINS, F. B.. Propaganda negativa na campanha presidencial em 2014. Ou como tudo que é frágil se desmancha no ar. Revista Estudos Políticos, v. 6, n. 1, p. 182-200, 2015

BRASIL. Tribunal Superior Eleitoral. Eleições 2014 \#vempraurna. Brasília, 2014. Disponível em: < http://www.tse.jus.br/eleicoes/eleicoes-2014/eleicoes-2014 >. Acesso em 3 nov. 2014. 
CARLOMAGNO, Márcio Cunha. Eleições como de costume? Uma análise longitudinal das mudanças provocadas nas campanhas eleitorais brasileiras pelos impactos das tecnologias digitais (1998-2014). In: CONGRESSO DA COMPOLÍTICA, 6., 22 a 24 abr. 2015, Rio de Janeiro. Anais... Rio de Janeiro: Compolítica, 2015.

CHAIA, Vera. Internet e eleições: as comunidades políticas no Orkut nas eleições de 2006. Logos 27: mídia e democracia, n. 27, p. 127-140, 2007.

DAMORE, David F.. Candidate strategy and the decision to go negative. Political Research Quarterly; Salt Lake City, v. 55, n. 3, p. 669-685, 2002.

DWORAK, Fernando. A favor de las campañas negativas: un alegato para México. Revista del Instituto de Ciencias Jurídicas de Puebla, n. 30, p. 118-135, 2012.

ELMELUND-PRÆESTEKÆR, Christian. Beyond American negativity: toward a general understanding of the determinants of negative campaigning. European Political Science Review, v. 2 , n. 1, p. 137-156, 2010.

FREITAS, Jéssica. Segundo turno presidencial é o mais acirrado da história. Terra, São Paulo. 21 out. 2014. Disponível em: < http://noticias.terra.com.br/eleicoes/segundo-turno-presidencial-eo-mais-acirrado-da-historia,f1aea71484339410VgnVCM3000009af154d0RCRD.html>. Acesso em: 03 nov. 2014.

HANSEN, K. M.; PEDERSEN, R. T.. Negative campaigning in a multiparty system. Scandinavian Political Studies, v. 31, n. 4, p. 408-427, 2008.

JAMIESON, Kathleen Hall. Dirty politics: Deception, distraction, and democracy. New York: Oxford University Press, 1992.

JOATHAN, Í.; MARQUES, F. P. J.. Campanha negativa e formas de uso do Facebook nas eleições presidenciais brasileiras de 2014. In: MOREIRA, A.; ARAÚJO, E.; SOUSA, H. (Eds.). Comunicação e Política: tempos, contextos e desafios, Braga: CECS, 2017.

KAID, L. L.; JOHNSTON, A.. Negative versus positive television advertising in U.S. presidential campaigns, 1960-1988. Journal of Communication, v. 41, n. 3, p. 53-64, 1991.

KLOTZ, Robert. Negative advertising on the internet in the 1996 senate races. Political Comuniccation, v. 15, n. 3, p. 347-365, 1998.

LAU, R. R.; POMPER, G. M.. Negative campaigning by US senate candidates. Party Politics, v. 7, n. 1, p. 69-87, 2001.

LOURENÇO, Luiz Cláudio. Abrindo a caixa-preta: da indecisão à escolha. A eleição presidencial de 2002. Tese (Doutorado em Ciências Humanas / Ciência Política) - Instituto Universitário de Pesquisas do Rio de Janeiro, 2007.

MARQUES, F. P. J. A.; SILVA, F. W. O.; MATOS, N. R.. Estratégias de comunicação política online: uma análise do perfil de José Serra no Twitter. Contemporânea - Revista de Comunicação e Cultura, v. 9, n. 3, p. 344-369, 2011.

MASSUCHIN; M. G.; TAVARES, C. Q.. Campanha eleitoral nas redes sociais: estratégias empregadas pelos candidatos à Presidência em 2014 no Facebook. Revista Compolítica, v. 5, n. 2, p. 75-112, 2015. 
ORLANDI, Eni Puccinelli. Análise de discurso: princípios e procedimentos. Campinas: Pontes, 2000.

PENTEADO, C. L. C.; PEREIRA, N. B.; FIACADORI, G.. O Planalto em disputa no Facebook: um estudo dos perfis de Dilma Rousseff e Aécio Neves nas eleições de 2014. In: CERVI, E. U.; MASSUCHIN, M. G.; CARVALHO, F. C. (Org.). Internet e Eleições no Brasil, Curitiba: CPOP, 2016

QUEIROZ, A. C. F.; TAVARES, D. C.. Marketing Político, História e Evolução no Brasil Republicano. In: CONGRESSO DA COMPOLÍTICA, 2., dez. 2007, Belo Horizonte. Anais... Belo Horizonte: Compolítica, 2007.

ROSSINI, P. G. C.; BAPTISTA, E. A.; OLIVEIRA, V. V.; SAMPAIO, R. C.. O uso do Facebook nas eleições presidenciais brasileiras: A influência das pesquisas eleitorais nas campanhas online. In: CERVI, E. U.; MASSUCHIN, M. G.; CARVALHO, F. C. (Org.). Internet e Eleições no Brasil, Curitiba: CPOP, 2016

SAMPAIO, Thiago. Ataques e contra-ataques: campanhas negativas na disputa presidencial de 2010. In: CONGRESSO DA COMPOLÍTICA, 5., 8 a 10 mai. 2013, Curitiba. Anais... Curitiba: Compolítica, 2013.

WALTER, Annemarie S.. Choosing the enemy: Attack behaviour in a multiparty system. Party Politics. v. 20, n. 3, p. 311-323, 2014.

\section{O autor}

Ícaro Joathan é doutorando em Comunicação na Universidade Federal Fluminense e bolsista de doutorado da Funcap. icarojoathan@gmail.com 